\title{
Confiscation and fundamental rights across criminal and non-criminal domains
}

\author{
Michele Simonato ${ }^{1}$
}

Published online: 19 September 2017

(C) The Author(s) 2017. This article is published with open access at Springerlink.com

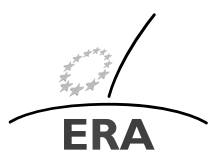

EUROPÄISCHE RECHTSAKADEMIE ACADEMY OF EUROPEAN LAW ACADEMIE DE DROIT EUROPEEN ACCADEMIA DI DIRITTO EUROPEO TRIER - TREVES - TREVIRI

\begin{abstract}
Confiscation is one important component of contemporary policies against serious crimes. International organisations are increasingly encouraging national legislators to introduce more effective and incisive tools to deprive criminals of the illicit gain, even in the absence of a final conviction. The risks of abuses and interferences with fundamental rights are, however, evident. On several occasions, the European Court of Human Rights (ECtHR) has dealt with cases involving various forms of confiscation, but many aspects are still debated. This article aims to provide an overview of the variegated case law from Strasbourg, highlighting recent and possible future developments.
\end{abstract}

Keywords Non-conviction-based confiscation - European Court of Human Rights (ECtHR) · Directive 2014/42/EU · Extended confiscation · Asset recovery · Fundamental rights

\section{Introduction}

In the past decades, several countries have introduced new forms of confiscation. Many have done so to comply with obligations under international and EU law, which are increasingly urging the development of strategies and tools aimed at depriving criminals of their illicit gain. The benefits of fighting 'dirty money' have been widely emphasized (punitive, preventive, reparative, etc.), and nowadays confiscation

$凶$ M. Simonato

m.simonato@uu.nl

1 Researcher at the Utrecht Centre for Regulation and Enforcement in Europe (Renforce), Utrecht University, Utrecht, The Netherlands 
is becoming one of the main objectives when dealing with organised crime and other serious offences, including corruption. ${ }^{1}$

Compared with a traditional concept of confiscation, whereby the deprivation of property (crime instrumentalities and proceeds) follows a conviction for a specific crime, the new forms of confiscation provide for a loosened link between offences and confiscated proceeds. Assets may be confiscated even if they are not proceeds of the crime for which the offender has been convicted (extended confiscation), ${ }^{2}$ if they belong to persons other than the offender (third party confiscation), or if they are the proceeds of an offence which has not been proven at trial (non-conviction based confiscation); in some cases, even if criminal proceedings against the suspect have not started at all (civil asset forfeiture). In all these cases, the fact that a previous fullyfledged assessment of the criminal conduct, and of the link with the assets, is not a decisive factor to apply a confiscation measure raises several questions as regards the general objectives of criminal justice systems and the balance between effectiveness and human rights.

Human rights law, however, has not yet provided a firm answer to all questions arising about the compatibility of new forms of confiscation with fundamental rights. In particular, the European Court of Human Rights (ECtHR) has a casuistic approach that makes it difficult to identify a solid framework to assess the legitimacy of confiscation regimes. ${ }^{3}$ As observed by judge Pinto de Albequerque in his (partly concurring and partly dissenting) opinion in the Varvara case:

'Under the nomen juris of confiscation, the States have introduced ante delictum criminal prevention measures, criminal sanctions (accessory or even principal criminal penalties), security measures in the broad sense, administrative measures adopted within or outside criminal proceedings, and civil measures in rem. Confronted with this enormous range of responses available to the State, the Court has not yet developed any consistent case-law based on principled reasoning'. ${ }^{4}$

The compelling questions concerning human rights, however, cannot be neglected, and the ECtHR — as well as the Court of Justice of the European Union (CJEU) — will be likely called again in the future to identify certain limits to confiscation measures that every State must respect. Recently, in Gogitidze, ${ }^{5}$ the ECtHR has tried to put forward a more comprehensive vision concerning non-conviction-based confiscation regimes, but still many issues remain without a clear answer. This article, without having the ambition of being exhaustive, aims to clarify some features of the recent ECtHR case law, and to point out some developments that can be expected in the future.

\footnotetext{
${ }^{1}$ Stessens [21]; Vervaele [23]; Manes [10]; Fernandez-Bertier [6].

${ }^{2}$ Blanco Cordero [2].

${ }^{3}$ Boucht [5].

${ }^{4}$ Varvara v. Italy, no. 17475/09, 29.10.2013.

${ }^{5}$ Gogitidze and others v. Georgia, no. 36862/05, 12.5.2015.
} 


\section{Common EU concepts of confiscation (and its limits)}

It is difficult to provide a full picture of the ECtHR case law with regard to all specific forms of confiscation. This is due to the fact that in this field, more than in other areas of criminal law, great differences exist among national regimes, and some countries have introduced peculiar forms that are hardly comparable with homologue foreign concepts (e.g., the anti-mafia preventive confiscation in Italy). ${ }^{6}$

It is worth mentioning, however, that in the last years, the EU has contributed to the development of a common narrative in this field. The objectives of the EU are not necessarily different from those pursued by other international organisations, such as the United Nations (UN) or the Council of Europe $(\mathrm{CoE})$. The EU, however, due to the type of binding instruments that it can adopt, has the potential to take a step further compared to a traditional international setting; for this reason, it has adopted several legal instruments, in some cases re-stating the obligations provided by international treaties, in other cases going beyond them. ${ }^{7}$

For example, the EU has been trying to make the already existing cooperation mechanisms swifter and more effective in practice (e.g., the Council Decision 2007/84/JHA concerning the cooperation between Asset Recovery Offices). ${ }^{8}$ Furthermore, it has adopted instruments applying the principle of mutual recognition to the cooperation during the investigations (Framework Decision 2003/577/JHA) ${ }^{9}$ and in the execution of confiscation decision (Framework Decision 2006/783/JHA); ${ }^{10}$ in this regard, the Commission has recently proposed the adoption of a Regulation that is supposed to recast the existing legal framework and to remedy its shortcomings. ${ }^{11}$ The most relevant efforts-at least for the purposes of this contribution-have been made as regards the harmonisation of national concepts of confiscation. In particular, Directive 2014/42/EU aims to put forward a common definition of extended confiscation, ${ }^{12}$ third party confiscation, ${ }^{13}$ and non-conviction based confiscation. ${ }^{14}$ As

\footnotetext{
${ }^{6}$ Panzavolta [17]; Nicosia [15].

${ }^{7}$ Borgers [3]; Fernandez-Bertier [6]; Ligeti/Simonato [9].

${ }^{8}$ Council Decision 2007/845/JHA of 6 December 2007 concerning cooperation between Asset Recovery Offices of the Member States in the field of tracing and identification of proceeds from, or other property related to, crime [2007] OJ L332/103. The objective is to ensure close co-operation and direct communication between national authorities involved in the tracing of illicit proceeds and other property that may become liable to confiscation (see Recital 3). For this purpose, each ARO established in one Member State is able to send a specific and detailed request for information to its counterpart in another Member State. The rules for this co-operation are those set forth in Framework Decision 2006/960/JHA of 18 December 2006 on simplifying the exchange of information and intelligence between law enforcement authorities of the Member States of the European Union [2006] OJ L386/89.

${ }^{9}$ Framework Decision 2003/577/JHA on the execution in the European Union of orders freezing property or evidence [2003] OJ L196/45.

${ }^{10}$ Framework Decision 2006/783/JHA of 6 October 2006 on the application of the principle of mutual recognition to confiscation orders [2006] OJ L328/59.

${ }^{11}$ Proposal for a Regulation of the European Parliament and the Council on the mutual recognition of freezing and confiscation orders, COM (2016) 819 final, 21 December 2016.

${ }^{12}$ See Art. 5 of Directive 2014/42/EU of 3 April 2014 on the freezing and confiscation of instrumentalities and proceeds of crime in the European Union [2014] OJ L 127/39.

${ }^{13}$ Art. 6 of Directive 2014/42/EU.

${ }^{14}$ Art. 4(2) of Directive 2014/42/EU.
} 
argued by other authors, ${ }^{15}$ not only the non-conviction based confiscation, but also the extended and the third-party confiscation can be considered to some extent as confiscations without previous conviction: in the extended confiscation, some of the confiscated assets derive from crimes for which there has not been any conviction, and the third parties owning the confiscated assets are, by definition, not involved in the criminal proceedings leading to the conviction.

This EU instrument should have been transposed into national law by October 2016, and no official evaluation of its implementation has been carried out yet. In any event, in some cases due to treaty limitations (e.g., as regards the impossibility to propose a more far reaching model of non-criminal forfeiture) and in others to the difficulties to reach a common approach within the Council, the provisions of Directive 2014/42/EU do not cover every aspect of confiscation measures. Hence a broad margin of discretion is left to national legislators. For example, as regards extended confiscation, the Directive does not clarify to what extent a reversal of the burden of proof is allowed, what offences can be taken into consideration to determine the amount of confiscated property, or what criteria can be used to prove the link of certain assets with previous criminal conduct. ${ }^{16}$ As regards non-conviction based confiscation, the EU provisions aim just at minimum harmonisation, since they suggest employing confiscation without conviction in very limited cases (i.e., if convictionbased confiscation is not possible due to illness or the absconding of the suspect) and it can be considered as a real obligation only for those countries that do not provide for in absentia proceedings. ${ }^{17}$ Most importantly, it does not deal with confiscation measures issued outside the context of a criminal procedure. However, this does not preclude Member States to provide for them, as it occurs, for example, in Italy, Ireland, Bulgaria, and the UK. ${ }^{18}$

It is worth mentioning that the Directive introduces a minimum level of procedural safeguards that must be implemented at national level, too: these basically consist of the obligation to communicate the order with its underlying reasons as well as the possibility of a judicial review. ${ }^{19}$ Nevertheless, no clear limits are incorporated in the substantive regulation of these new confiscation measures. The EU legal framework does not even explicitly preclude, for example, the confiscation of all assets of the convicted person. ${ }^{20}$ For this reason, the ECtHR case law plays an important role in the identification of the limits to such afflictive measures, and in the future a similar role could be played by the CJEU, which may be called to clarify the scope and content of the Charter of Fundamental Rights of the European Union (CFREU) in this context.

\footnotetext{
${ }^{15}$ Panzavolta [17].

${ }^{16}$ See Boucht [4]; Simonato [20].

${ }^{17}$ See Recital 15 of Directive 2014/42/EU.

${ }^{18}$ Rui/Sieber [19].

${ }^{19}$ Art. 8 of Directive 2014/42/EU.

${ }^{20}$ Some limits can be found in Recitals 17 and 18. See Maugeri [12].
} 


\section{The key question: confiscation as a criminal sanction?}

The identification of the fundamental rights that have to be protected, and to what extent, depends on a preliminary crucial question concerning the nature of a confiscation measure: is it a criminal sanction, or can it be considered as a different type of measure, different from a penalty? Obviously, only in the first case the full set of principles and safeguards applicable to criminal law cases must apply. For example, Article 6(2) and Article 6(3) ECHR would be engaged, and some features of civil proceedings - such as the standard of proof based on the balance of probabilities instead of the beyond any reasonable doubt principle - could be considered in contrast with due (criminal) process standards. Similarly, the principle of legality enshrined in Article 7 ECHR would be triggered, thereby imposing a non-retroactive legal basis. Even the ne bis in idem principle (Article 4 Protocol 7 ECHR) could be at stake, for example, if proceedings targeting assets were linked to a crime for which a final decision has already been issued.

The question about the nature of confiscation arises because national law often does not label a confiscation measure as a penalty, but rather as a security measure, a preventive measure, or as a measure not aimed at the punishment of the culprit but at the neutralisation of criminal profit and at the removal of illegal proceeds from the licit economy. It is well-known, however, that the ECtHR adopts an autonomous concept of criminal matter, independent of national labels. Since the Engel judgment, the ECtHR has developed some criteria to assess whether a certain measure is substantially punitive, regardless of its formal classification at the national level. These criteria include the nature of the offence and the degree of severity of the sanction.

Already at this point, however, when looking at the way in which these criteria have been applied to confiscation measures, it is quite difficult to decipher the rationale behind the ECtHR case law. ${ }^{21}$ In some cases, measures that were defined as non-criminal by national law were treated as a penalty by the ECtHR. In other similar cases, the national classification has been upheld by the judges in Strasbourg.

An example of the first case, where the national label was re-qualified, concerns a confiscation measure for the illegal construction of buildings labelled as administrative in Italy ('confiscation of land'). It was applied despite the eventual acquittal of the defendant, on the basis of the consideration that the actus reus was ascertained during the criminal proceedings. Italian courts, indeed, concluded that the building had been illegally built; however, since the local authority had granted the authorisation, they found that the accused was not guilty of negligence and had not had any unlawful intent: the law governing the authorisation system was not clear enough and the defendant's mistake was unavoidable. On the basis of these facts, in Sud Fondi the ECtHR condemned Italy for a violation of Article 7 ECHR, since the legal basis for the offence did not satisfy the criteria of clarity, accessibility and foreseeability. Consequently, it was impossible to foresee that a penalty could be inflicted. ${ }^{22}$

Some years later, another case concerning the same kind of 'administrative' confiscation was brought before the ECtHR: in this case, the criminal proceedings had

\footnotetext{
${ }^{21}$ Ivory [8], p. 150.

${ }^{22}$ Sud Fondi Srl v. Italy, no. 75909/01, 20.1.2009.
} 
been discontinued on the grounds that the prosecution had become time-barred after the applicant had been convicted in the first degree ${ }^{23}$ nonetheless, a confiscation measure was applied. In Varvara, the ECtHR considered that measure as a penalty, and punishing a defendant whose trial has not resulted in a conviction as incompatible with Article 7 ECHR:

'a system which punished persons for an offence committed by another would be inconceivable. Nor can one conceive of a system whereby a penalty may be imposed on a person who has been proved innocent or, in any case, in respect of whom no criminal liability has been established by a finding of guilt'. 24

It is worth mentioning that such a judgment concerning an administrative confiscation, issued after an acquittal due to time-barred prosecution, has sparked a judicial 'dialogue' — as a matter of fact a rather conflictual—with the Italian Constitutional Court, who held that Italian courts are obliged to implement only those ECtHR judgments that reflect a 'consolidated case law'. According to the Italian Court, this is not the case for Varvara, which is just the result of the casuistic approach followed by the judges in Strasbourg. ${ }^{25}$ A new case, currently pending before the Grand Chamber (a hearing was held in September 2015, but the judgment has not been issued yet), will further clarify the approach of the ECtHR to the Italian 'confiscation of land' measure, applied even if the criminal proceedings have been discontinued as time-barred or there was no charge against the owners. ${ }^{26}$

In several other cases, the ECtHR has re-considered the national labelling of a confiscation measure. Such a European re-labelling — it is worth stressing it—does not entail a prohibition of providing for non-criminal confiscation. It just means that certain fundamental rights provided by the ECHR as regards criminal penalties must be respected. In Welch, for example, dealing with the retrospective application of a confiscation measure related to drug trafficking, which was considered by the British legislator as a preventive measure aimed at removing the value of the proceeds from possible future use in the drugs trade, the ECtHR held that in reality the confiscation amounted to a penalty within the meaning of Article 7 ECHR, and that therefore it could not have retroactive application. To reach such a conclusion the ECtHR observed, on the one hand, that the purpose of the measure is not conclusive, since the 'aims of prevention and reparation are consistent with a punitive purpose and may be seen as constituent elements of the very notion of punishment' ${ }^{27}$ and, on the other hand, that not even the severity of the measure is decisive, since 'many non-penal measures of a preventive nature may have a substantial impact on the person concerned'. ${ }^{28}$ The Court, therefore, found indications of a regime of punishment in other

\footnotetext{
${ }^{23}$ Contrary to the Sud Fondi case, therefore, the acquittal was not a decision on the merits.

${ }^{24}$ Varvara v. Italy, no. 17475/09, 29.10.2013, § 66-67.

${ }^{25}$ Italian Constitutional Court, 26.3.2015, no. 49.

${ }^{26}$ G.I.E.M. s.r.l. v. Italy, Hotel promotion Bureau s.r.l. and Rita Sarda s.r.l. v. Italy, Falgest s.r.l. and Gironda v. Italy, nos. 1828/06, 34163/07, and 19029/11.

${ }^{27}$ Welch v. The United Kingdom, no. 17440/90, 9.2.1995, § 31.

${ }^{28}$ Welch v. The United Kingdom, no. 17440/90, 9.2.1995, § 32.
} 
factors, such as the existence of statutory presumptions that reverse the burden of proof, the fact that the order was not limited to actual enrichment or profit but to all proceeds of crime, the discretion left to the judge, and the fact that a confiscation order could be converted into a prison sentence.

Of course, the criminal nature of a confiscation measure has important consequences for the presumption of innocence. In Paraponiaris, a pecuniary measure was applied to the applicant after he had been acquitted because of a time-barred prosecution, since the national courts held that the offence was 'objectively' ascertained despite the eventual acquittal. In this case, the ECtHR found a violation of Article 6(2) ECHR since the application of a sanction after an acquittal, because the offence had actually been committed, is comparable to a determination of guilt without a due process. ${ }^{29}$ A violation of the presumption of innocence was also found in Geerings, where the Court condemned the Netherlands because an extended confiscation order, issued after a conviction, covered assets deriving from crimes for which the applicant had been previously acquitted. This, according to the ECtHR, amounted to a determination of guilt without the applicant having been found guilty according to law. ${ }^{30}$

As stated, a point of criticism often raised toward the case law of the ECtHR concerns its incoherence, and therefore the unpredictability of its outcome in a specific case. This might be due, for example, to the fact that the ECtHR often seems to ground its conclusions on the assessment of the purpose of the measure, excluding the nature of penalty whenever there is not a clear punitive aim. Recently, for example, the Georgian civil forfeiture system has been repeatedly challenged before the Court. Such a system allows enforcement authorities to recover assets wrongfully or inexplicably accumulated by public officials accused of certain offences, without obtaining their conviction. In these cases, however, the ECtHR has underlined that the forfeiture of property as a result of civil proceedings which does not involve the determination of a criminal charge, is not of a punitive but of a preventive and/or compensatory nature, and therefore does not entail the application of Article 6(2) and 6(3) ECHR. ${ }^{31}$

In the famous case Phillips - concerning the English regime of extended confiscation, i.e. a conviction-based confiscation also of assets deriving from other criminal conduct, for which there has been no conviction-the ECtHR was asked to establish whether the applicant was subject to new charges (as regards the assets deriving from un-proven criminal conduct) and, if not, whether the presumption of innocence produced an effect, notwithstanding the absence of new charges. ${ }^{32}$ The main argument leading the Court to find Article 6(2) ECHR non-applicable to those facts is that the purpose of the reference to other criminal conduct 'was not the conviction or acquittal of the applicant for any other drug-related offence' but 'to enable the national court

\footnotetext{
${ }^{29}$ Paraponiaris v. Greece, no. 42132/06, 25.9.2008. See Panzarasa [16], p. 1691.

${ }^{30}$ Geerings v. The Netherlands, no. 30810/03, 1.3.2007.

${ }^{31}$ Gogitidze and others v. Georgia, no. 36862/05, 12.5.2015; Giorgi Devadze v. Georgia, no. 21727/05, 3.11.2016.

${ }^{32}$ Phillips v. The United Kingdom, no. 41087/98, 5.7.2001. See also Van Offeren v. The Netherlands (dec.), no. 19581/04, 5.7.2005; and Walsh v. The United Kingdom, no. 43384/05, 21.11.2006.
} 
to assess the amount at which the confiscation order should properly be fixed'. In other words, the Court considered the reference to other offences only as a criterion to determine the extent of the confiscation, operating in the sentencing phase (for the judged offences) but not representing a new charge for the other non-judged offences allegedly committed by the convicted person.

As to the other prong of the question-whether the presumption of innocence applies even if no new charges are brought-the ECtHR noted that Article 6(2) ECHR 'can have no application in relation to allegations made about the accused's character and conduct as part of the sentencing process, unless such accusations are of such a nature and degree as to amount to the bringing of a new "charge" within the autonomous Convention meaning' without further elaborating on the nature and degree of those specific accusations deriving from the confiscation procedure. Furthermore, the ECtHR held that the reversal of the burden of proof - provided in the UK in order to ascertain the link between assets and other offences - did not violate the notion of a fair hearing under Article 6(1) ECHR. According to the ECtHR, the applicant benefited from adequate safeguards: among them, a public hearing where he could adduce documentary and oral evidence, and the effective possibility to rebut the presumption of the criminal origin of the assets targeted by the extended confiscation.

In Butler, a case brought against the United Kingdom concerning its regime of civil asset forfeiture related to drug trafficking — which, according to the applicant, is criminal in nature and should, therefore, attract the safeguards of the criminal process - the Court declared the application inadmissible ratione materiae. The main reason is that those kind of forfeiture orders do not involve the determination of any criminal charge, more or less like the reference to other criminal conduct in extended confiscation assessed in Phillips. This makes it incomparable with a criminal sanction, since the civil asset forfeiture regime applied in the case under scrutiny "was designed to take out of circulation money which was presumed to be bound up with the international trade in illicit drugs' ${ }^{33}$

On several occasions, the Italian anti-mafia preventive confiscation regime has been considered as a non-criminal measure, too. Since several decades, Italy has introduced a peculiar system of rather burdensome 'preventive measures', both personal (i.e., limiting the liberty of persons) and patrimonial (i.e., touching upon their property). They are devised to tackle organised crime more effectively than criminal proceeding, since they can be applied to persons who are not convicted, but only suspected of being connected to a mafia organisation (or, since more recently, involved in other serious offences). As regards the patrimonial side, the nature of that peculiar confiscation has been long debated in Italian case law, which tends to emphasise its preventive non-criminal facet, and literature, which is generally much more critical of the non-criminal label and the consequent lowering of safeguards. ${ }^{34}$ It is worth mentioning that the scope of application of these measures is being further extended by the legislator in these very months.

\footnotetext{
${ }^{33}$ Butler v. United Kingdom (dec.), no. 41661/98, 27.6.2002.

${ }^{34}$ Mazzacuva [13]; Panzavolta/Flor [18].
} 
The ECtHR has never found this kind of preventive confiscation to be criminal in nature and to attract the safeguards typical of criminal proceedings. ${ }^{35}$ The only aspect that determined a condemnation of Italy for a violation of the civil limb of Article 6 ECHR has been the lack of the possibility to request a public hearing to decide their application. ${ }^{36}$ This led some authors to observe that the ECtHR has been 'tolerant' ${ }^{37}$ and has 'shown a readiness to display considerable deference towards how states construct and use asset confiscation as a means of crime control' ${ }^{38}$

\section{Confiscation as something other than a criminal sanction}

If the answer to the question concerning the nature of a confiscation measure, even after applying the Engel criteria, is that confiscation is not a penalty, but a different kind of measure, it does not follow - of course - that fundamental rights do not apply at all, but just that different rights, or different aspects of those rights, are at stake. Consequently, certain safeguards can be diluted, but do not disappear: a legal basis is still necessary even if the legality principle is less stringent; the defence rights are those that fall within the civil limb of Article 6 (instead of the full set of guarantees provided for criminal proceedings); the standard of proof can be based on the balance of probabilities instead of the beyond any reasonable doubt; the use of presumption (thereby the reversal of the burden of proof) can be more extensive, etc. ${ }^{39}$

How much weaker the protection of fundamental rights outside the realm of criminal law can be, however, is not self-evident. European and national case law, as well as scholarly literature, are still struggling to identify which safeguards ought to apply to non-criminal (or quasi-criminal, being in any case a component of the public response to crime) confiscation proceedings. Rather that within the scope of Article 6 and 7 , the answer is sought in the realm of the right to property. Article 1, Protocol 1, ECHR provides, indeed, that no one can be deprived of his possessions 'except in the public interest and subject to the conditions provided for by law and by the general principles of international law'. The ECtHR has clarified that this means that the Convention requires a legal basis for any interference with the 'peaceful enjoyment' of one's possessions (lawfulness), and that such an interference, based on public interests, is proportionate to the legitimate aim pursued (proportionality). ${ }^{40}$

\footnotetext{
${ }^{35}$ Arcuri and others v. Italy (dec.), no. 52024/99, 5.7.2001; Licata v. Italy (dec.), no. 32221/02, 27.5.2004; Riela and others (dec.), no. 52439/99, 4.9.2001.

${ }^{36}$ Bocellari and Rizza v. Italy, no. 399/02, 13.11.2007; Bongiorno and others v. Italy, no. 4514/07, 5.1.2010.

${ }^{37}$ Panzavolta [17].

${ }^{38}$ Boucht [5], p. 23.

${ }^{39}$ Panzavolta [17], p. 34.

${ }^{40}$ More precisely, the Court held that 'where a confiscation measure has been imposed independently of the existence of a criminal conviction but rather as a result of separate "civil" (...) judicial proceedings aimed at the recovery of assets deemed to have been acquired unlawfully, such a measure, even if it involves the irrevocable forfeiture of possessions, constitutes nevertheless control of the use of property within the meaning of the second paragraph of Article 1 of Protocol No. 1' (Gogitidze and others v. Georgia, no. 36862/05, 12.5.2015, § 94).
} 
As regards the lawfulness, the ECtHR clarified that, in order to ensure adequate protection against arbitrary action on the part of the authorities, it exercises a scrutiny on the 'quality of the law', in the sense that the requirement of lawfulness means also compatibility with the rule of law. Domestic rules, therefore, must be sufficiently precise and foreseeable, and the law must provide legal protection against arbitrariness. Recently, for example, the ECtHR condemned Bulgaria in a case concerning a civil forfeiture order issued against unexplained - therefore allegedly 'unlawful' income. One of the reasons for the violation of Article 1, Protocol 1, ECHR was identified in the fact that no time limits were set for the possibility of the State requiring evidence about personal revenues and expenditure. Therefore, in principle, prosecution authorities would be free to 'open, suspend, close and open again proceedings at will at any time'. 41

In this regard, it is worth mentioning that there is the possibility that the ECtHR approach to the Italian preventive confiscation (see above) might change if the Court decides to go down the road recently taken by the Grand Chamber in De Tommaso. ${ }^{42}$ That case concerned the application of praeter delictum personal 'preventive measures', namely a sort of special police supervision accompanied by several obligations (such as not changing place of residence, or leading a 'honest and law-abiding life'). In that case, the ECtHR held that such measures violated Article 2 Protocol 4 ECHR, which provides that any measure restricting the liberty of movement must be adopted in accordance with domestic law, pursue one of the legitimate aims referred to in the third paragraph of that Article, and strike a fair balance between the public interest and the individual's rights. The Court recalled that the legal basis to adopt such measures must be accessible to the persons concerned and foreseeable to its effects: this means that the law, in order to protect individuals against arbitrary interferences by the public authorities, must be formulated 'with sufficient precision to enable citizens to regulate their conduct; they must be able-if need be with appropriate advice- to foresee, to a degree that is reasonable in the circumstances, the consequences which a given action may entail'. ${ }^{43}$ This is not the case with such measures, according to the ECtHR, since Italian law does not clearly identify the 'factual evidence' or the specific types of behaviour that can be taken into consideration to assess the dangerousness of the individual, which may give rise to the preventive (personal) measure; in other words, the vagueness of the law regulating the conditions to apply such measures, as well as their content, does not provide sufficient protection against arbitrary interferences with the freedom of movement.

Although this case concerns personal measures, there might be consequences on the future case law concerning the preventive non-conviction-based confiscation, since the two legal regimes, and the requirements to apply the respective measures, are quite similar. ${ }^{44}$ As said above, the ECtHR did not consider the Italian personal preventive measures as criminal in nature: only the civil aspects of Article 6 ECHR were considered applicable, and no violation was found in that respect. Hence despite

\footnotetext{
${ }^{41}$ Dimitrovi v. Bulgaria, no. 12655/09, 3.3.2015, § 46.

${ }^{42}$ De Tommaso v. Italy, no. 43395/09, 23.2.2017.

${ }^{43}$ De Tommaso v. Italy, no. 43395/09, 23.2.2017, § 107.

${ }^{44}$ Viganò [24].
} 
the various arguments used by scholars and dissenting judges, ${ }^{45}$ there are no real reasons to expect that this is likely to happen soon with regard to patrimonial preventive measures. Nevertheless, applying to patrimonial measures the reasoning followed by the ECtHR in De Tommaso (as regards the personal measures) may lead to a more severe scrutiny of the 'quality of law' needed to adopt measures restricting the right to property. ${ }^{46}$

As regards the proportionality, it is worth mentioning that this concept is not explicitly mentioned in the ECHR, but has acquired an important role due to the development of the ECtHR case law especially as regards the 'qualified rights', i.e. those non-absolute rights that can be subject to legitimate limitations, such as the right to private life, the right to manifest one's religion or belief, the right to freedom of expression, and indeed the right to property. The proportionality test is conducted when there is an interference with a fundamental right, and aims to assess whether such an interference pursues a legitimate objective, whether the measure is suitable to reach that objective, whether it is necessary (i.e., if no other less intrusive means were available) and whether it is proportionate to the final objective (proportionality stricto sensu). ${ }^{47}$ This implies, in other words, an assessment of the relation between means and ends, which requires a fair balance between the competing interests protected by the human right and those of the community as a whole. ${ }^{48}$

In some cases, the ECtHR has affirmed that an interference with the right to property violates the principle of proportionality — compromising the fair balance between individual right and general interest-when an excessive burden is imposed on the property-owner. In Paulet, the applicant complained that the confiscation orders (following a conviction for obtaining employment using a false passport) had been disproportionate as it amounted to the confiscation of his entire savings over nearly four years of genuine work, without any distinction being made between his case and those involving more serious criminal offences such as drug trafficking or organised crime. The Court specified that, '[a]lthough the second paragraph of Article 1 of Protocol No. 1 contains no explicit procedural requirements, the Court must consider whether the proceedings as a whole afforded the applicant a reasonable opportunity for putting his case to the competent authorities with a view to enabling them to establish a fair balance between the conflicting interests at stake'. ${ }^{49}$ This was not the case in the domestic proceedings, according to the ECtHR: the UK courts simply considered that the confiscation order had been issued in the public interests, but they did not go further to conduct the other aspects of the proportionality test, meaning they did not balance the interference in the public interest with the right to peaceful enjoyment of an individual's possessions as recognised by the ECHR. The scope of their review, in

\footnotetext{
${ }^{45}$ In his partly dissenting opinion in De Tommaso, judge Pinto de Albuquerque explains why he considers these preventive measures criminal in nature in light of the Engel criteria.

${ }^{46}$ Judge Pinto de Albuquerque ( $\$ 60$ ) concluded that 'the Italian legislature evidently has to draw all the logical conclusions from the present judgment with regard to the recent Legislative Decree no. 159/2011, and the sooner the better.

${ }^{47}$ See Alexy [1].

${ }^{48}$ See, as regards Art. 8 ECHR, Von Hannover v. Germany, no. 59320/00, 24.6.2004, § 57.

${ }^{49}$ Paulet v. The United Kingdom, no. 6219/08, 13.5.2014, § 65.
} 
other words, had been too narrow to satisfy the requirement of seeking a fair balance between opposite interests.

In Microintelect, a case dealing with Bulgarian forfeiture in administrative punitive proceedings concerning the selling of alcohol without the required authorisation, the ECtHR stressed that, when finding the balance between property rights and general interests, the States have a wide margin of appreciation when passing laws for the purpose of securing the payment of taxes, since decisions in this area "commonly involve the consideration of political, economic and social question which the Convention leaves within the competence of the Contracting States' ${ }^{50}$ In that case, however, Bulgaria was condemned for a violation of Article 1, Protocol 1, ECHR because the applicant—a 'third party' whose property was affected-could not intervene in the proceedings against the alleged offender. In addition, since there was no legal basis for a judicial review of the decision, the Court did not find that national law provided adequate safeguards against unjustified interferences with property rights.

Even the assessment of the proportionality of the interference with the right to property may, therefore, be influenced by the level of procedural safeguards granted to the applicant. In Webb, for example, the Court observed that the applicant had an adversarial procedure before the national authorities who decided on the (noncriminal) forfeiture, and that proceedings applying the civil standard of proof do not entail that the measure is disproportionate. In that case, a potential violation of Article 6(1) ECHR (civil limb) was rather identifiable in the lack of reasoning for the decision. However, the application was declared inadmissible because of the nonexhaustion of all domestic remedies. ${ }^{51}$

This emerged even more clearly in the above-mentioned Gogitidze, a case concerning non-conviction based confiscation related to corruption offences, where the ECtHR recognised the legitimacy, in the anti-corruption field, of 'internationally acclaimed standards' concerning in rem confiscation measures that entail, inter alia, the possibility of lowering the standard of proof and to tackle assets belonging to third parties ('family members and other closer relatives who were presumed to possess and manage the ill-gotten property informally on behalf of the suspected offenders, or who otherwise lacked the necessary bona fide status'). Assessing, and confirming, the proportionality of the national measures, the ECtHR stressed that States have a wide margin of appreciation with regard to what constitutes the appropriate means of applying measures to control the use of property. ${ }^{52}$ Most decisively, the Court acknowledged that the applicants were afforded 'a reasonable opportunity of putting their arguments before the domestic courts', both in writing and at an oral hearing; that the proceedings were conducted in an adversarial manner; and that the domestic courts duly examined the prosecutor's claim in the light of numerous supporting documents available in the case file. ${ }^{53}$

All in all, there are not many cases in which the Court found the interference with property rights disproportionate as such. This is not surprising, since there are no

\footnotetext{
${ }^{50}$ Microintelect Odd v. Bulgaria, no. 34129/03, 4.3.2014, § 42. See also Aboufadda v. France, no. 28457/10, 4.11.2014, § 22 .

${ }^{51}$ Webb v. The United Kingdom (dec.), no. 56054/00, 10.2.2004.

${ }^{52}$ Gogitidze and others v. Georgia, no. 36862/05, 12.5.2015, § 108.

${ }^{53}$ Gogitidze and others v. Georgia, no. 36862/05, 12.5.2015, § 109-113.
} 
clear cut criteria to determine what amounts to a disproportionate interference with the right to property. Proportionality, as developed by the ECtHR, is a rather 'procedural' concept, which serves as an analytical framework that may lead to different results according to the specific weight of the various factors taken into consideration in the different contexts, particularly those related to the procedure that led to the adoption of the confiscation order. ${ }^{54}$ Such a reliance on proportionality in human rights adjudication has been subject to criticism because of the lack of clear guidance to the judge as to how to determine when a concrete measure does not represent a fair balance, or when the adopted means could be proportionate to the legitimate objective. ${ }^{55}$ As regards measures against the right to property, the ECtHR has shown a tendency to apply a less stringent proportionality test compared with the one conducted as regards other fundamental rights, ${ }^{56}$ in particular when such measures are part of an enforcement strategy against serious crimes like drug trafficking, organised crime, and-more recently-corruption. Also for this reason, one may conclude that the protection offered by the ECHR as regards the right to property is lower than that provided by the full set of provisions of Article 6 and 7 ECHR. The question of the true nature of confiscation measures, therefore, maintains its relevance.

\section{Conclusions}

Confiscation has been increasingly acquiring a prominent place in the design of criminal policies in the field of organised crime and terrorism, but also more in general in the field of economic and financial crime. The interest of national legislators and practitioners in fostering the effectiveness of measures against criminal property has certainly risen in the last years. The risks of such a trend are to be assessed by taking into consideration the various fundamental rights endangered by these measures. At the national level, domestic courts are struggling to find a balance between effectiveness of crime control mechanisms and protection of human rights. In the European context, both the ECHR and the CFREU contain provisions that imply certain limits to confiscation measures, and a minimum level of safeguards for convicted persons, defendants, or simple property owners. So far, the ECtHR has dealt with a number of cases involving examples of extended, non-conviction based, and third party confiscation, i.e. the most recent and afflictive forms of confiscation. In the future, the CJEU may be asked to clarify the content and scope of the rights provided by the CFREU.

Safeguards and limits differ depending on whether confiscation measures are criminal in nature or not. The criminal limb of Article 6 ECHR, as well as Article 7 ECHR, apply to confiscation measures whose nature is that of a penalty, whatever the national label is. The assessment of the nature carried out by the ECtHR is, therefore, crucial to determine the violation of those conventional rights. However, the application of

\footnotetext{
${ }^{54}$ McBride [14]; Harbo [7], p. 63; Boucht [5], p. 168; Marletta [11].

${ }^{55}$ Urbina [22], pp. 2-7.

${ }^{56}$ Boucht [5], p. 174.
} 
the long-established criteria to guide such an assessment-national qualification, nature of the offence, and severity of the sanction-do not always lead to predictable and consistent outcomes. The assessment seems to strongly depend on the purpose of the sanction-preventive and/or compensatory rather than punitive-but this is a debatable approach, since penalties too may combine punitive with preventive purposes. $^{57}$

In the future, therefore, the Court may strive to refine the common European understanding of criminal charge and criminal sanction, further clarifying the distinction between punitive, preventive and reparative purposes. As several authors suggest, to make the outcome of its case law more predictable and unfluctuating, the ECtHR might also endeavour to find a more 'principled reasoning' to distinguish the various forms of confiscation, based for example on the forfeitable object or the procedure followed to adopt the measure. ${ }^{58}$ In any event, given the blurred boundaries between criminal and non-criminal measures, what falls outside the criminal law domain should not be neglected. In this regard, it will be interesting to see whether the ECtHR will modify its tolerant approach to non-criminal measures, by exercising a stricter scrutiny of national laws and practices with regard to the quality and foreseeability of domestic law interfering with the fundamental right to property, and the proportionality of such an interference.

Open Access This article is distributed under the terms of the Creative Commons Attribution 4.0 International License (http://creativecommons.org/licenses/by/4.0/), which permits unrestricted use, distribution, and reproduction in any medium, provided you give appropriate credit to the original author(s) and the source, provide a link to the Creative Commons license, and indicate if changes were made.

\section{References}

1. Alexy, R.: Constitutional rights and proportionality (2014). Revus [online] 22

2. Blanco Cordero, I.: Modern forms of confiscation and protection of third parties. In: Ligeti, K., Simonato, M. (eds.) Chasing Criminal Money. Challenges and Perspectives on Asset Recovery in the EU, p. 139. Hart Publishing, Oxford (2017)

3. Borgers, M.J.: Confiscation of the proceeds of crime: the European Union framework. In: King, C., Walker, C. (eds.) Dirty Assets. Emerging Issues in the Regulation of Criminal and Terrorist Assets, p. 27. Ashgate, Farnham (2014)

4. Boucht, J.: Extended confiscation: criminal assets or criminal owners? In: Ligeti, K., Simonato, M. (eds.) Chasing Criminal Money. Challenges and Perspectives on Asset Recovery in the EU, p. 117. Hart Publishing, Oxford (2017)

5. Boucht, J.: The Limits of Asset Confiscation. On the Legitimacy of Extended Appropriation of Criminal Proceeds. Hart Publishing, Oxford (2017)

6. Fernandez-Bertier, M.: The confiscation and recovery of criminal property: a European Union State of the Art. ERA Forum 323, 17 (2016)

7. Harbo, T.: The Function of Proportionality Analysis in European Law. Brill Nijhoff, Leiden (2015)

8. Ivory, R.: Corruption, Asset Recovery, and the Protection of Property in Public International Law: The Human Rights of Bad Guys. Cambridge University Press, Cambridge (2014)

9. Ligeti, K., Simonato, M.: Asset recovery in the EU: towards a comprehensive enforcement model beyond confiscation? An introduction. In: Ligeti, K., Simonato, M. (eds.) Chasing Criminal Money. Challenges and Perspectives on Asset Recovery in the EU, p. 1. Hart Publishing, Oxford (2017)

\footnotetext{
${ }^{57}$ Mazzacuva [13]. See also the partly dissenting opinion of judge Pinto de Albuquerque in De Tommaso, $\S 37$.

${ }^{58}$ Boucht [5]; Panzavolta [17].
} 
10. Manes, V.: L'ultimo imperativo della politica criminale: nullum crimen sine confiscatione. Rivista italiana di diritto e procedura penale, 1259 (2015)

11. Marletta, A.: Il principio di proporzionalità della disciplina. del mandato d'arresto europeo (Cedam, forthcoming)

12. Maugeri, A.M.: La Direttiva 2014/42/UE relativa alla confisca degli strumenti e dei proventi da reato nell'Unione europea tra garanzie ed efficienza: un "work in progress". Diritto penale contemporaneo. Rivista trimestrale, 300 (2015)

13. Mazzacuva, F.: The problematic nature of asset recovery measures: recent developments of the Italian preventive confiscation. In: Ligeti, K., Simonato, M. (eds.) Chasing Criminal Money. Challenges and Perspectives on Asset Recovery in the EU, p. 101. Hart Publishing, Oxford (2017)

14. Mc Bride, J.: Proportionality and the European convention on human rights. In: Ellis, E. (ed.) The Principle of Proportionality in the Laws of Europe, p. 23. Hart Publishing, Oxford (1999)

15. Nicosia, E.: La confisca, le confische. Giappichelli (2012)

16. Panzarasa, M.: Confisca senza condanna? Uno studio de lege lata e de iure condendo sui presupporti processuali dell'applicazione della confisca. Rivista italiana di diritto e procedura penale, 1672 (2010)

17. Panzavolta, M.: Confiscation and the concept of punishment: can there be a confiscation without a conviction? In: Ligeti, K., Simonato, M. (eds.) Chasing Criminal Money. Challenges and Perspectives on Asset Recovery in the EU, p. 25. Hart Publishing, Oxford (2017)

18. Panzavolta, M., Flor, R.: A necessary evil? The Italian "non-criminal" system of asset forfeiture. In: Rui, J.P., Sieber, U. (eds.) Non-Conviction-Based Confiscation in Europe. Possibilities and Limitations on Rules Enabling Confiscation Without a Criminal Conviction, p. 111. Duncker \& Humblot, Berlin (2015)

19. Rui, J.P., Sieber, U.: NCBC in Europe: bringing the picture together. In: Rui, J.P., Sieber, U. (eds.) Non-Conviction-Based Confiscation in Europe, p. 263. Duncker \& Humblot, Berlin (2015)

20. Simonato, M.: Extended confiscation of criminal assets: limits and pitfalls of minimum harmonisation in the EU. Eur. Law Rev. 727, 41 (2016)

21. Stessens, G.: Money Laundering. A New International Enforcement Model. Cambridge University Press, Cambridge (2000)

22. Urbina, F.J.: A Critique of Proportionality and Balancing. Cambridge University Press, Cambridge (2017)

23. Vervaele, J.: Economic crimes and money laundering: a new paradigm for the criminal justice system? In: Unger, B., van der Linde, D. (eds.) Research Handbook on Money Laundering, p. 379. Edward Elgar, Cheltenham Glos (2013)

24. Viganò, F.: La Corte di Strasburgo assesta un duro colpo alla disciplina italiana delle misure di prevenzione personali (3 March 2017). Available at http://www.penalecontemporaneo.it/d/5264la-corte-di-strasburgo-assesta-un-duro-colpo-alla-disciplina-italiana-delle-misure-di-prevenzione-p 